\title{
Reevaluation of Seroprevalence using a Semi-quantitative Anti-spike IgG in Health Care workers at an Academic Medical Center in Boston, Massachusetts
}

Manisha Cole $e^{1,2}$, Elizabeth R. Duffy ${ }^{2}$, Jordyn N Osterland ${ }^{1,2}$, Susan Gawel ${ }^{3}$, Lei Ye ${ }^{3}$, Kyle de la Cena $^{2}$, Elizabeth J. Ragan ${ }^{4}$, Sarah E. Weber ${ }^{4}$, Elissa M- SchechterPerkins $^{5}$, Tara C. Bouton ${ }^{4}$, Karen R. Jacobson ${ }^{4}$, Chris Andry ${ }^{1,2}$, Yachana Kataria ${ }^{1,2^{*}}$

${ }^{1}$ Department of Pathology and Laboratory Medicine, Boston Medical Center, Boston, MA

${ }^{2}$ Department of Pathology and Laboratory Medicine, Boston University School of Medicine, Boston, MA

${ }^{3}$ Abbott Laboratories, Department of Biostatistics

${ }^{4}$ Section of Infectious Diseases, Boston Medical Center, Boston, MA

${ }^{5}$ Department of Emergency Medicine, Boston University School of Medicine / Boston Medical Center, Boston, MA

Running Title: SARS-CoV-2 lgG Semi-Quantitative Assay

\section{Conflict-of-interest disclosure}

The authors declare no competing financial interests.

\section{Corresponding Author}

Yachana Kataria, PhD, DABCC

Medical Director, Clinical Chemistry

Department of Pathology and Lab Medicine

670 Albany St.

Boston, MA 02118

Tel: $617-414-3727$

Email: Yachana.Kataria@bmc.org

\section{Abstract (250 words)}

Background: Accurate measurement of antibodies is a necessary tool for assessing exposure to SARS-CoV-2 and facilitating understanding of the role of antibodies in immunity. Most assays are qualitative in nature and employ a threshold to determine presence of antibodies. Semiquantitative assays are now available. Here we evaluate the semi-quantitative SARS-CoV-2 lgG II (anti-spike (S)) assay. We aim to reassess the seroprevalence using anti- S assay and subsequently compare it to the previously measured $\lg G$ (anti-nucleoprotein $(\mathrm{N})$ ) in health care workers at an academic medical center in Boston. 
44 Methods: 1743 serum samples from HCWs at Boston Medical Center were analyzed for SARS-

45 CoV-2 anti-S IgG and IgM using the Abbott SARS-CoV-2 IgG II and $\square$ Abbott AdviseDx $\square$ SARS-

46 CoV-2 IgM assay, respectively. Precision, linearity, positive and negative concordance with prior

47 RT-PCR test were evaluated for anti-S IgG. Seroprevalence and its association with

48 demographics variables was also assessed.

Results: Linearity and precision results were clinically acceptable. The positive and negative concordance for anti-S IgG with RT-PCR was $88.2 \%(95 \% \mathrm{Cl}: 79.4 \%-94.2 \%)$ and $97.43 \%$

52 (95\% Cl: 95.2\% - 98.8\%), respectively. Overall, $126(7.2 \%)$ of 1,743 participants were positive

53 by anti-S IgG. Among the 1302 participants with no prior RT-PCR, 40 (3.1\%) were positive for

54 anti-S $\lg G$ antibody. The original agreement in this population with the qualitative, anti-N $\lg G$ assay was $70.6 \%$. Upon optimizing the threshold from 1.4 to $0.49 \mathrm{~S} / \mathrm{CO}$ of the anti-N IgG assay, the positive agreement of the assay increases to $84.7 \%$.

Conclusion: The anti-S IgG assay demonstrated reproducible and reliable measurements. This

59 study highlights the presence of asymptomatic transmission among individuals with no prior

60 history of positive RT-PCR. It also highlights the need for optimizing thresholds of the qualitative

61 SARS-CoV-2 IgG assay for better agreement between assays by the same vendor. 
medRxiv preprint doi: https://doi.org/10.1101/2022.01.20.22269543; this version posted January 21, 2022. The copyright holder for this preprint (which was not certified by peer review) is the author/funder, who has granted medRxiv a license to display the preprint in perpetuity.

It is made available under a CC-BY-NC-ND 4.0 International license .

\section{Introduction}

70 Coronavirus disease 2019 (COVID-19) is the disease caused by the novel severe acute

71 respiratory syndrome coronavirus 2 (SARS-CoV-2) that causes fever, cough, shortness of

72 breath, and fatigue that can quickly become life threatening (1-3). SARS-CoV-2 RNA testing

73 alone, in the absence of serological testing, is not sufficient to assess population-level viral

74 transmission and pathogen exposure and the public health burden of the pandemic (4). The

75 transient nature of RNA testing makes it an inaccurate metric to assess viral transmission at a

76 population level. Accurate measurement of antibodies can facilitate understanding the role of

77 antibodies in immunity elicited by both natural and vaccine response $(5,6)$. Ongoing studies are

78 investigating the durability of antibodies against SARS-CoV-2 and examining what levels confer

79 protective immunity against severe disease and/or reinfection (6-9).

81 There has been a rapid increase in serological assay availability in the United States via

82 Emergency Use Authorization (EUA) from the Food and Drug Administration (FDA)(4, 10).

83 These assays are designed to detect different immunoglobulin classes (IgM, $\lg G, \lg A)$ or total

84 antibodies to various epitopes of SARS-CoV-2. SAR-CoV-2 epitopes include the spike (S) or

85 nucleocapsid $(\mathrm{N})$ proteins. Most currently approved assays are qualitative in nature and employ

86 a threshold to determine the presence of antibodies. Semi-quantitative assays are now

87 available. To date, there are over 15 semi-quantitative assays approved for clinical testing in the

88 United States including Roche Elecsys Anti-SARS-CoV-2 S, Phadia, Beckman Coulter, Inc.

89 Access SARS-CoV-2 IgG II, AB EliA SARS-CoV-2-Sp1 IgG Test Phadia, Dimension EXL

90 SARSCoV2 IgG, and Quanterix Simoa Semi-Quantitative SARS-CoV-2 IgG Antibody Test

91 among others (11). However, it remains unclear if the pre-defined threshold for current

92 qualitative and semi-quantitative assays is appropriately set $(4,12)$. It is also unclear whether

93 these SARS-CoV-2 serological assays are comparable which prohibits assessment of durability

94 and correlation with protection to help inform public health policies $(4,13)$. 
medRxiv preprint doi: https://doi.org/10.1101/2022.01.20.22269543; this version posted January 21, 2022. The copyright holder for this preprint

(which was not certified by peer review) is the author/funder, who has granted medRxiv a license to display the preprint in perpetuity.

It is made available under a CC-BY-NC-ND 4.0 International license.

95

96 We previously assessed seroprevalence among health care workers at an

97 (11)(11)(11)academic medical center in Boston, Massachusetts, USA using the qualitative

98 assay SARS-CoV-2 lgG (anti-nucleoprotein (N)) assay (11). Seroprevalence studies can assist

99 in detecting asymptomatic and symptomatic infection and provide a cumulative prevalence

100 estimate. Abbott Laboratories has now been issued an EUA for its anti-spike quantitative SARS-

101 CoV-2 $\lg G$ II (anti-S $\lg G$ ) and $\lg M($ anti-S $\lg M)$ assay (6). In this study, we aim to reevaluate the

102 seroprevalence in health care worker (HCW) population using the anti-S IgG assay and

103 compare it to the anti-N $\lg G$ assay.

104

105

106

107 


\section{Methods}

\section{Study Design \& Participants}

110 Baseline samples were obtained from an ongoing longitudinal cohort assessing COVID-19

111 serological status among HCW's at Boston Medical Center (BMC). In brief, participants were

112 adult BMC employees who worked on campus during the first COVID-19 surge in Boston, MA

113 (March 13th-May 31st, 2020). Baseline serum samples were obtained between July 13th-26th,

$1142020(n=1,743)$ and had been previously analyzed for anti-N IgG antibody status (Abbott

115 Laboratories, Abbott Park, IL). Participants completed extensive questionnaire data on

116 demographics (age, gender, race, ethnicity) between January $1^{\text {st }}-$ My $31^{\text {st }}, 2020$. Prior RT-

117 PCR COVID-19 test results completed at BMC during the same period, were confirmed in

118 the electronic medical record. This project was approved by the Institutional Review Board at

119 Boston University Medical Center (BUMC).

121 For the current investigation, we analyzed serum samples for SARS-CoV-2 anti-S IgG \& IgM (n

$122=1,743)$. These assays were performed by the clinical pathology laboratory at BMC on the

123 Abbott Architect i2000 Instrument (Abbott Laboratories, Abbott Park, IL). Assays were run per

124 the manufacturer's instructions. For both assays, aliquots of serum samples ( 500 ul) were

125 thawed for either 24 hours at $4^{\circ} \mathrm{C}$ or 2 hours at room temperature prior to being analyzed.

129 SARS-CoV-2 IgM Assay (Qualitative)

130 The $\square$ AdviseDx $\square$ SARS-CoV-2 IgM (anti-S IgM) assay is a chemiluminescent microparticle

131 immunoassay (CMIA) for the qualitative $\square$ detection of lgM antibody in human serum against the

132 SARS-CoV-2 spike protein. $\square \square$ 
134 In this automated assays, participant serum, paramagnetic particles coated with SARS-CoV-2

135 antigen, and an assay diluent are incubated together during which the antibodies present in the

136 serum sample bind to the antigen. The resulting luminescence will be read and resulted as a

137 relative light unit $(\mathrm{RLU})$. Both assays rely on an assay-specific calibrator to report a ratio of

138 specimen RLU to calibrator RLU. Interpretation of positivity is determined by an index

139 value above a predefined threshold $(8,9)$.

141 IgM samples were interpreted as positive (index value $\geq 1.00$ ) or negative (index value $<1.00$ ).

142 Both qualitative and quantitative results were used in the analysis.

\section{Anti-S IgG Assay (Semi-Quantitative)}

145 Aliquots of serum samples ( 500 ul) were thawed for either 24 hours at $4^{\circ} \mathrm{C}$ or 2 hours at room temperature prior to being analyzed.

148 The Abbott ARCHITECT SARS-CoV-2 IgG II assay is a semi-quantitative assay that detects $149 \lg \mathrm{G}$ antibodies to the receptor binding domain (RBD) of the S1 subunit of the spike protein of 150 SARS-CoV-2 in human plasma. It is a two-step indirect CMIA.

152 The assay utilizes magnetic microparticles coated with RBD recombinant protein. The mixture is

153 incubated and then washed prior to the addition of an anti-human-IgG antibody conjugated to

154 acridinium. The recorder molecule is incubated prior to a second wash and followed by addition

155 of a triggering solution that generates luminescence. The light is captured and counted to give

156 an RLU. The RLU's are read of a six-point calibration curve stored on the instrument generating

157 an $\mathrm{AU} / \mathrm{mL}$ (arbitrary units/milliliter) value. The assay is standardized to a monoclonal antibody

158 concentration (14). Samples were interpreted as positive when $>=50.0 \mathrm{AU} / \mathrm{mL}$ or negative

159 when $<50.0 \mathrm{AU} / \mathrm{mL}$. Both qualitative and quantitative results were used in the analysis. 


\section{Precision SARS-CoV-2 IgM \& Anti-S IgG}

162 Precision studies were performed on quality control (QC) material as supplied by Abbott

163 Diagnostics. IgM has two levels of QC: negative and positive. Anti-S IgG has three levels of QC:

164 negative, low positive, and high positive. Intra-day precision was assessed by analyzing 20

165 replicates of each level of QC on the same day. Inter-day precision was assessed by analyzing

166 QC for 20 days.

\section{Linearity Anti-S IgG Studies}

169 The analytical measuring range of anti-S $\lg \mathrm{G}$ is $22.0-25,000 \mathrm{AU} / \mathrm{mL}$. The suggested

170 manufacturer dilution is $1: 2$, extending the measuring upper limit to $50,000 \mathrm{AU} / \mathrm{mL}$.

171 Dilution studies were carried out using two participants that had elevated serum samples.

172 Although the EUA approved upper linearity is $25,000 \mathrm{AU} / \mathrm{mL}$, reagent was received prior to EUA

173 approval and was reported to be $50,000 \mathrm{AU} / \mathrm{mL}$ at the time of these analyses. These samples

174 were diluted serially with negative control. A total of 7 levels were tested in triplicates on the

175 Abbott Architect i2000 instrument.

177 Statistical Analysis

178 Questionnaire data were collected and managed in REDCap electronic data capture tools

179 hosted at Boston University, CTSI 1UL1TR001430 (15, 16). Imprecision was assessed by

180 measuring mean, standard deviation (SD), and coefficient of variation (CV) for inter and intra-

181 day precision. Anti-S lgG data were log transformed (base 2) for analysis and ease of

182 visualization. 
184 Categorical data are presented as counts. We tested the association between anti-S IgG with

185 sex, race, and gender using a Fisher's Exact Test analysis. Missing data of less than $5 \%$ was

186 excluded from analysis.

188 Positive and negative concordance of anti-S IgG was calculated using molecular testing (RT-

189 PCR) as the gold standard among participants with a prior RT-PCR test result. Comparison

190 between assays was assessed by Mcnemar's chi-squared test. Receiver operating

191 characteristics (ROC) curve was used to assess assay thresholds and define trade-offs in assay

192 sensitivity and specificity using to RT-PCR test as the gold standard.

194 A P-value of < 0.05 was considered statistically significant, and all tests were two-sided.

195 Analyses were performed in R Version R-3.5.3 (R Foundation for Statistical Computing). Select

196 figures were produced by GraphPad Prism version (9.0.2) by GraphPad Software (San Diego, 197 USA).

199 Results

201 Precision

202 IgM negative and positive control exhibited an intra-day CV of $16.5 \%$, and $2.2 \%$, respectively.

203 IgM negative and positive control exhibited an inter-day CV of $21.3 \%$, and $1.9 \%$, respectively

\section{4 (Supplementary Table 1).}

206 Anti-S IgG negative, low positive, and high positive control exhibited an intra-day CV of $23.9 \%$,

$2073.3 \%$, and 2.9\%, respectively. Anti-S IgG negative, low positive, and high

208 positive control exhibited an inter-day CV of $16.6 \%, 2.4 \%$, and $2.4 \%$, respectively

209 (Supplementary Table 1). 


\section{Anti-S IgG Linearity}

212 Linearity data is shown in Figure 1. Figure 1a displays a participant result with greater than the

213 analytical measuring range $(46,820 \mathrm{AU} / \mathrm{mL})$ and shows an acceptable linear response with a r-

214 squared value of 0.99 . Similarly, Figure 1b displays a participant result that had an original anti-

215 S IgG level of $11,711.60 \mathrm{AU} / \mathrm{mL}$ with acceptable linearity with a r-squared value of 0.99 , though

216 not at the upper end of the analytical measuring range.

217

218

219

220 The data suggests that the difference between expected and measured is within the $95 \% \mathrm{Cl}$.

221 Significant percentage differences are observed on the lower end of the analytical measuring

222 range (Supplementary Figure 1).

\section{Seroprevalence}

225 Table 1 shows demographics in relation to anti-S IgG status ( $n=1,743$ ). Overall, 126 of 1,743

226 (7.23\%) participants were anti-S IgG positive. Participants who were female, Hispanic, or Black

227 were more likely to be seropositive, but these findings did not reach statistical significance.

228 Obese participants were two times more likely to be seropositive for anti-S IgG [RR: 2.04 (95\%

229 Cl: 1.40, 2.99)]. Among all the participants, anti-S lgG levels were not associated with age, race,

230 or gender (Figure 2a-c).

232 Figure 2 - Anti-S IgG by demographics - a). Age b). Gender c). Race

234441 of 1743 participants had a history of RT-PCR test. 47 of 85 RT-PCR

235 confirmed positive individuals were also seropositive by $\lg \mathrm{M}$ corresponding to a positive

236 concordance of $55.3 \%(95 \% \mathrm{Cl}: 44.1 \%-66.1 \%) .343$ of 350 RT-PCR confirmed 
237 negative participants were seronegative by IgM corresponding to a negative concordance of

$23898.0 \%$ (95\% Cl: 95.9\% - 99.2\%) (Supplementary Table 2). Of the remaining six participants

239 with indeterminate RT-PCR results, two had detectable lgM antibody.

24175 of the 85 RT-PCR confirmed positive participants were also seropositive by anti-S IgG

242 corresponding to a positive concordance of $88.2 \%(95 \% \mathrm{Cl}: 79.4 \%-94.2 \%)$. 341 of $350 \mathrm{RT}$ -

243 PCR confirmed negative participants were seronegative by anti-S IgG corresponding to a

244 negative concordance of $97.43 \%$ (95\% Cl: $95.2 \%-98.8 \%)$ (Table 2). A total of 1302

245 participants had no prior RT-PCR test and of these participants, 40 (3.1\%) were positive by anti-

246 S IgG. Distribution of the anti-S IgG levels by RT-PCR test result is shown in Figure 3. Among

247 the individuals with a prior RT-PCR, there is a statistically significant difference among the anti-

248 S IgG levels by RT-PCR test result $(p<0.001)$.

Figure 3 - Anti-S IgG distribution by SARS-CoV-2 RT-PCR status

252 A total of 270 of the 441 individuals with a prior RT-PCR test had a recorded date of RT-PCR.

253 Figure 4 displays anti-S IgG level distribution since RT-PCR date. There was no statistical

254 difference between anti-S levels in individuals less than 120 days after positive RT-PCR test

255 result ( $p=0.16)$ (Supplementary Figure 2). Anti-S IgG antibodies in RT-PCR confirmed

256 individuals remained elevated over 120 days post infection.

257 Figure 4 - Anti-S IgG distribution days post SARS-CoV-2 RT-PCR result

\section{Agreement between Anti-N IgG vs. Anti-S IgG Status}

260 Overall agreement between the two assays in this population was found to be $97.5 \%(95 \% \mathrm{Cl}$ :

$26196.7 \%-98.2 \%)$. Of note, the positive agreement was $70.6 \%(95 \% \mathrm{Cl}: 61.8 \%-78.4 \%)$, whereas 
262 the negative agreement was $99.6 \%(95 \% \mathrm{Cl}: 99.2 \%-99.9 \%)$. These two tests were found to be

263 statistically different $(p<0.001)$.

265 A total of 37 participants had detectable anti-S IgG but were negative by anti-N IgG (Table

266 3a). Of these, 11 participants had a positive RT-PCR, 3 participants had a negative RT-PCR,

2671 participant had an indeterminate RT-PCR, and 22 were not tested. Of interest, 6 participants

268 had detectable anti-N IgG results but were negative by anti-S lgG.

269 Table 3 - Anti-N lgG vs. Anti-S IgG Agreement

\section{Assay Threshold Optimization}

272 ROC curve analysis showed that the SARS-CoV-2 IgG qualitative had optimal sensitivity and

273 specificity target e.g., adjusting threshold to 0.49 S/CO would result in a sensitivity of $84.7 \%$ and

274 specificity of at least 96.9\% (Supplementary Figure 3).

276 As such, changing the threshold of positivity for the anti-N IgG assay from 1.4 to $0.49 \mathrm{~S} / \mathrm{CO}$ ratio

277 increased the positive agreement between anti-N $\lg G$ \& anti-S $\lg$ from $70.6 \%$ to $86.5 \%(95 \%$

$278 \mathrm{Cl}$ : 79.3\% - 91.9\%). However, it did not appreciably affect the negative agreement, from $99.6 \%$

279 to $98.7 \%(95 \% \mathrm{Cl}: 98.0 \%-99.2 \%)$ (Table 3b). Upon threshold modification, the two anti-N IgG

280 vs. anti-S IgG were found to be statistically aligned.

\section{Discussion}

285 This study reevaluates the seroprevalence in HCWs using a semi-quantitative anti-S IgG assay.

286 It also compares the findings to the anti-N IgG in the same population. We report an overall 
medRxiv preprint doi: https://doi.org/10.1101/2022.01.20.22269543; this version posted January 21, 2022. The copyright holder for this preprint (which was not certified by peer review) is the author/funder, who has granted medRxiv a license to display the preprint in perpetuity.

It is made available under a CC-BY-NC-ND 4.0 International license .

seroprevalence of $7.2 \%$. Among participants with a negative RT-PCR $2.5 \%$ of participants had detectable anti-S IgG antibody. We also observed a seroprevalence of $3.1 \%$ among participants with no prior RT-PCR. Our results demonstrate that the anti-S \& anti-N IgG assays were statistically different. Upon lowering the anti-N IgG assay threshold, overall agreement between

291 the two assays improved. Taken together, these results support the clinical utility of anti-S IgG

292 assay and highlight the presence of COVID-19 infection among individuals with a negative or no 293 prior RT-PCR.

295 The anti-S IgG shows acceptable intra- and inter-day precision. The precision for the negative 296 control is expected to be high due to a lower numerical value and small variations observed 297 artificially increase the CV. Our results depict acceptable linearity up to $50,000 \mathrm{AU} / \mathrm{mL}$ which 298 exceeds upper limit stated in the package insert. It is currently unclear what titer levels confer 299 SARS-CoV-2 immunity but our data suggest that such elevated levels are not rare among the 300 participants.

302 Our results indicate less than ideal positive concordance for anti-S IgG vs. RT-PCR testing 303 which is inconsistent with the manufacturer claims. Further investigation of the discordant 304 samples $(n=10)$ unveil that these participants did not have detectable anti-N $\lg G$, or $\lg M$ 305 antibody. These findings can possibly be explained by mild symptoms and/or disease. Literature 306 suggests that the intensity and longevity of antibody response is associated with disease 307 severity (17-19). The negative concordance of the SARS-CoV-2 assay was robust and 308 consistent with the manufacturer claims.

310 Neither SARS-CoV-2 anti-N nor anti-S IgG assays find an association with sex, race, smoking 311 status. However, the seroprevalence determined by anti-S lgG assay was higher (7.2\%) relative 312 to the anti-N $\lg$ assay (5.5\%) (8). The observed seroprevalence at a regional Boston area 
medRxiv preprint doi: https://doi.org/10.1101/2022.01.20.22269543; this version posted January 21, 2022. The copyright holder for this preprint (which was not certified by peer review) is the author/funder, who has granted medRxiv a license to display the preprint in perpetuity.

It is made available under a CC-BY-NC-ND 4.0 International license .

313 hospital was comparable to ours (20). Whereas others in the larger Boston region have reported

314 a seroprevalence range between $14 \%$ to $25 \%$ (21). Seroprevalence can vary between sampling

315 times and geographic regions. Among participants that had no prior RT-PCR test, 40

316 participants had detectable anti-S IgG antibody and 23 participants had detectable anti-N lgG

317 antibody. As such, 17 additional individuals were identified to have IgG antibodies. This

318 suggests higher sensitivity of the anti-S IgG assay which is corroborated by others (22).

319 Alternatively, it may be attributable to a shorter half-life of anti-N $\lg G$ antibody (7).

321 These individuals pose a risk of asymptomatic viral transmission. Studies suggest that

322 asymptomatic individuals are a source of transmission even after being vaccinated (23-25).

323 Ultimately, RT-PCR testing is limited by the brief infectious window during which viral detection

324 is possible. Detectable viral loads during infection via RT-PCR can vary by several factors such

325 as patient medical history, immune response, and medications, whereas antibody

326 measurements can detect exposure to virus for longer periods of time $(26,27)$. Our data

327 suggests that participants in the study had elevated anti-S lgG for at least 120 days after RT-

328 PCR tests. The longevity of detectable antibody remains unclear especially in less severe

329 infections.

331 The qualitative nature of the anti-N IgG assay enabled us to optimize the pre-set threshold.

332 Upon changing the anti-N IgG threshold, the assays exhibit better agreement with anti-S IgG. 20

333 of the 37 discordant participant samples became concordant. The remainder (14/17) discordant

334 participants did not have a prior RT-PCR test, or a robust anti-N IgG response and most also

$335(12 / 17)$ had a negative $\operatorname{lgM}$. This suggests either a false positive anti-S IgG result or early

336 detection of the seroconversion process in asymptomatic individuals. We have been following

337 part of this cohort longitudinally and aim to determine if these individuals mount a permanent

338 immune response over time. Furthermore, a study conducted by Public Health England also 
medRxiv preprint doi: https://doi.org/10.1101/2022.01.20.22269543; this version posted January 21, 2022. The copyright holder for this preprint (which was not certified by peer review) is the author/funder, who has granted medRxiv a license to display the preprint in perpetuity.

It is made available under a CC-BY-NC-ND 4.0 International license .

339 independently suggested the same optimized threshold to increase the sensitivity of the assay

340 (28). Of interest, the same cut-off is currently used in Europe and provides external validation of

341 our findings. Taken together, our data lend further support for optimizing the assay threshold to

342 achieve better performance characteristics.

344 These differences between serological assays are also observed between vendors as well. In a

345 head-to-head comparison of five semi-quantitative SARS-CoV-2 IgG assays found that the

346 results from assays are not interchangeable despite good correlation to neutralizing antibody for

347 some of them (10). This has been supported by others $(9,29,30)$. Collectively, this highlights

348 the need for harmonization between all serological assays. This is of paramount importance as

349 it will enable us to draw meaningful conclusions about correlation of immunity and being better

350 equipped to overcoming the SARS-CoV-2 pandemic.

352 The present study benefited from a large sample size. Certain limitations are acknowledged.

353 The gold standard for determining protective antibody is a virus neutralization test which we

354 were unable to compare to the anti-N \& anti-S assay as it requires live pathogen and a biosafety

355 level 3 laboratory. The study is limited by a cross sectional study design which may under- or

356 overestimate the seroprevalence. We were unable to correlate days since RT-PCR result or

357 viral load with quantitative antibody levels and it may provide insight about antibody kinetics

358 (31). The samples were obtained from a single timepoint preventing characterization of antibody

359 kinetics on performance characteristics; however, a subset of participants is being prospectively

360 followed in three-month intervals which will enable future analysis. Lastly, the findings are not

361 generalizable to the larger community and is limited to hospitals.

363 In conclusion, the Abbott SARS-CoV-2 anti-S IgG assay demonstrate acceptable performance

364 characteristics. The study highlights the presence of infection among participants with no RT- 
medRxiv preprint doi: https://doi.org/10.1101/2022.01.20.22269543; this version posted January 21, 2022. The copyright holder for this preprint (which was not certified by peer review) is the author/funder, who has granted medRxiv a license to display the preprint in perpetuity. It is made available under a CC-BY-NC-ND 4.0 International license .

365 PCR testing and among those with a negative RT-PCR test. It also highlights the need for

366 optimizing thresholds of the qualitative SARS-CoV-2 IgG assay for better agreement between

367 assays by the same vendor. Serological testing can aid in identify a better assessment of the

368 public health burden.

369

370

371

372

373

374

375

376

377

378

379

380

381

382

383

384

385

386

387

388

389 
medRxiv preprint doi: https://doi.org/10.1101/2022.01.20.22269543; this version posted January 21, 2022. The copyright holder for this preprint

(which was not certified by peer review) is the author/funder, who has granted medRxiv a license to display the preprint in perpetuity.

It is made available under a CC-BY-NC-ND 4.0 International license.

390 Conflicts

391 Abbott Diagnostics provided the reagents for the SARS-CoV-2 IgG II assays.

392

393 Acknowledgements

394 We would like to acknowledge the clinical chemistry, phlebotomy, and central receiving staff in

395 the Department of Laboratory Medicine and Pathology at Boston Medical Center for working

396 with the research team to accomplish this study.

397

$398 \quad$ Funding

399 The study was funded, in part, by BMC Development Philanthropy Funds for COVID-19

400 research. Abbott Diagnostics provided the reagents for the SARS-CoV-2 IgG II assays.

401

402

403

404

405

406

407

408

409

410

411

412

413 
medRxiv preprint doi: https://doi.org/10.1101/2022.01.20.22269543; this version posted January $21,2022$. The copyright holder for this preprint (which was not certified by peer review) is the author/funder, who has granted medRxiv a license to display the preprint in perpetuity.

It is made available under a CC-BY-NC-ND 4.0 International license .

\section{References}

1. Symptoms 2020 [Available from: https://www.cdc.gov/coronavirus/2019ncov/symptoms-testing/symptoms.html.

2. Wiersinga WJ, Rhodes A, Cheng AC, Peacock SJ, Prescott HC. Pathophysiology, Transmission, Diagnosis, and Treatment of Coronavirus Disease 2019 (COVID-19): A Review. JAMA. 2020;324(8):782-93.

3. Asselah T, Durantel D, Pasmant E, Lau G, Schinazi RF. COVID-19: Discovery, diagnostics and drug development. J Hepatol. 2021;74(1):168-84.

4. National S-C-SAEG. Performance characteristics of five immunoassays for SARS-CoV-2: a head-to-head benchmark comparison. Lancet Infect Dis. 2020;20(12):1390-400.

5. Coste AT, Jaton K, Papadimitriou-Olivgeris M, Greub G, Croxatto A. Comparison of SARSCoV-2 serological tests with different antigen targets. J Clin Virol. 2021;134:104690.

6. Perkmann T, Perkmann-Nagele N, Koller T, Mucher P, Radakovics A, Marculescu R, et al. Anti-Spike Protein Assays to Determine SARS-CoV-2 Antibody Levels: a Head-to-Head Comparison of Five Quantitative Assays. Microbiol Spectr. 2021:e0024721.

7. Van Elslande J, Gruwier L, Godderis L, Vermeersch P. Estimated half-life of SARS-CoV-2 anti-spike antibodies more than double the half-life of anti-nucleocapsid antibodies in healthcare workers. Clin Infect Dis. 2021.

8. Kataria Y, Cole M, Duffy E, de la Cena K, Schechter-Perkins EM, Bouton TC, et al. Seroprevalence of SARS-CoV-2 IgG antibodies and risk factors in health care workers at an academic medical center in Boston, Massachusetts. Sci Rep. 2021;11(1):9694.

9. Bradley BT, Bryan A, Fink SL, Goecker EA, Roychoudhury P, Huang ML, et al. Anti-SARSCoV-2 Antibody Levels Measured by the AdviseDx SARS-CoV-2 Assay Are Concordant with Previously Available Serologic Assays but Are Not Fully Predictive of Sterilizing Immunity. J Clin Microbiol. 2021;59(9):e0098921.

10. Perkmann T, Perkmann-Nagele N, Koller T, Mucher P, Radakovics A, Marculescu R, et al. Anti-Spike protein assays to determine post-vaccination antibody levels: a head-to-head comparison of five quantitative assays. medRxiv. 2021:2021.03.05.21252977.

11. EUA Authorized Serology Test Performance: Food and Drug Administration; 2021 [Available from: https://www.fda.gov/medical-devices/coronavirus-disease-2019-covid-19emergency-use-authorizations-medical-devices/eua-authorized-serology-test-performance. 12. Eyre DW, Lumley SF, O'Donnell D, Stoesser NE, Matthews PC, Howarth A, et al. Stringent thresholds in SARS-CoV-2 IgG assays lead to under-detection of mild infections. BMC Infect Dis. 2021;21(1):187.

13. Jaaskelainen AJ, Kuivanen S, Kekalainen E, Ahava MJ, Loginov R, Kallio-Kokko H, et al. Performance of six SARS-CoV-2 immunoassays in comparison with microneutralisation. J Clin Virol. 2020;129:104512.

14. Laboratories A. AdviseDx SARS-CoV-2 IgG II 2021 [Available from: https://www.fda.gov/media/146371/download.

15. Harris PA, Taylor R, Thielke R, Payne J, Gonzalez N, Conde JG. Research electronic data capture (REDCap)--a metadata-driven methodology and workflow process for providing translational research informatics support. J Biomed Inform. 2009;42(2):377-81. 
medRxiv preprint doi: https://doi.org/10.1101/2022.01.20.22269543; this version posted January 21, 2022. The copyright holder for this preprint (which was not certified by peer review) is the author/funder, who has granted medRxiv a license to display the preprint in perpetuity. It is made available under a CC-BY-NC-ND 4.0 International license .

16. Harris PA, Taylor R, Minor BL, Elliott V, Fernandez M, O'Neal L, et al. The REDCap consortium: Building an international community of software platform partners. J Biomed Inform. 2019;95:103208.

17. Wang Y, Zhang L, Sang L, Ye F, Ruan S, Zhong B, et al. Kinetics of viral load and antibody response in relation to COVID-19 severity. J Clin Invest. 2020;130(10):5235-44.

18. Ravichandran S, Lee Y, Grubbs G, Coyle EM, Klenow L, Akasaka O, et al. Longitudinal antibody repertoire in "mild" versus "severe" COVID-19 patients reveals immune markers associated with disease severity and resolution. Sci Adv. 2021;7(10).

19. Ibarrondo FJ, Fulcher JA, Goodman-Meza D, Elliott J, Hofmann C, Hausner MA, et al. Rapid Decay of Anti-SARS-CoV-2 Antibodies in Persons with Mild Covid-19. N Engl J Med. 2020;383(11):1085-7.

20. Self WH, Tenforde MW, Stubblefield WB, Feldstein LR, Steingrub JS, Shapiro NI, et al. Seroprevalence of SARS-CoV-2 Among Frontline Health Care Personnel in a Multistate Hospital Network - 13 Academic Medical Centers, April-June 2020. MMWR Morb Mortal Wkly Rep. 2020;69(35):1221-6.

21. Bruno-Murtha LA, Osgood R, Lan FY, Buley J, Nathan N, Weiss M, et al. SARS-CoV-2 antibody seroprevalence after the first wave among workers at a community healthcare system in the Greater Boston area. Pathog Glob Health. 2021:1-4.

22. Fenwick C, Croxatto A, Coste AT, Pojer F, Andre C, Pellaton C, et al. Changes in SARSCoV-2 Spike versus Nucleoprotein Antibody Responses Impact the Estimates of Infections in Population-Based Seroprevalence Studies. J Virol. 2021;95(3).

23. Harris RJ, Hall JA, Zaidi A, Andrews NJ, Dunbar JK, Dabrera G. Effect of Vaccination on Household Transmission of SARS-CoV-2 in England. N Engl J Med. 2021;385(8):759-60.

24. Mostaghimi D, Valdez CN, Larson HT, Kalinich CC, Iwasaki A. Prevention of host-to-host transmission by SARS-CoV-2 vaccines. Lancet Infect Dis. 2021.

25. Po Ying Chia SWXO, Calvin J Chiew, Li Wei Ang, Jean-Marc Chavatte, Tze-Minn Mak, Lin Cui, Shirin Kalimuddin, Wan Ni Chia, Chee Wah Tan, Louis Yi Ann Chai, Seow Yen Tan, Shuwei Zheng, Raymond Tzer Pin Lin, Linfa Wang, Yee-Sin Leo, Vernon J Lee, David Chien Lye, Barnaby Edward Young. Virological and serological kinetics of SARS-CoV-2 Delta variant vaccinebreakthrough infections: a multi-center cohort study. MEDRxiv. 2021.

26. Tahamtan A, Ardebili A. Real-time RT-PCR in COVID-19 detection: issues affecting the results. Expert Rev Mol Diagn. 2020;20(5):453-4.

27. Kim JY, Ko JH, Kim Y, Kim YJ, Kim JM, Chung YS, et al. Viral Load Kinetics of SARS-CoV-2 Infection in First Two Patients in Korea. J Korean Med Sci. 2020;35(7):e86.

28. Public Health England PD, Nuffield Department of Medicine UoO, Trust OUHNF.

Evaluation of sensitivity and specificity of four commercially available SARS-CoV-2 antibody immunoassays. Public Health England. 2020.

29. Kim Y, Lee JH, Ko GY, Ryu JH, Jang JH, Bae H, et al. Quantitative SARS-CoV-2 Spike Antibody Response in COVID-19 Patients Using Three Fully Automated Immunoassays and a Surrogate Virus Neutralization Test. Diagnostics (Basel). 2021;11(8). 
30. Ekelund O, Ekblom K, Somajo S, Pattison-Granberg J, Olsson K, Petersson A. Highthroughput immunoassays for SARS-CoV-2 - considerable differences in performance when comparing three methods. Infect Dis (Lond). 2021;53(10):805-10. epidemic dynamics in observational seroprotection studies. medRxiv. 2020.

Legend:

Figure 1 - Linearity of Anti-S IgG

Table 1 - Population Demographics by Anti-S IgG quant

Figure 2 - Anti-S IgG by demographics - a). Age b). Gender c). Race

Figure 1 - Linearity of Anti-S IgG

\section{Participant 1}

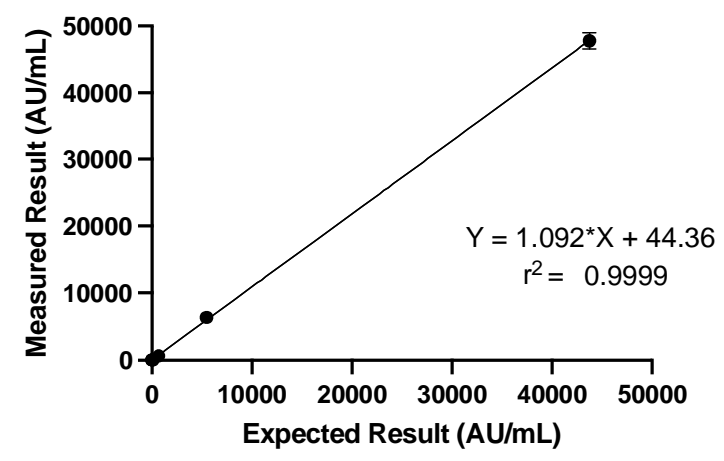

Participant 2

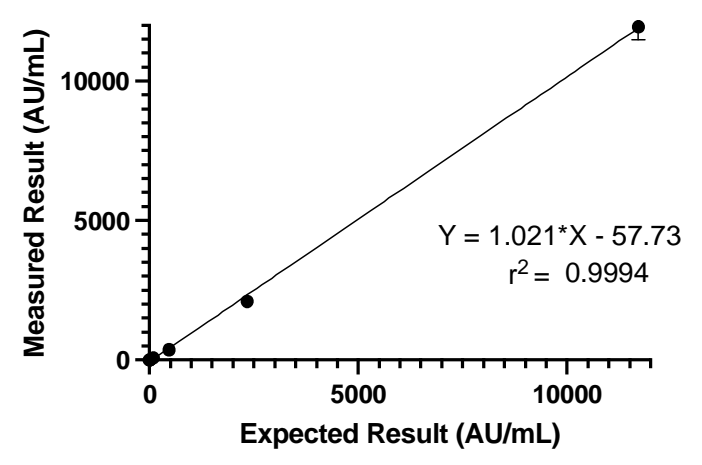


medRxiv preprint doi: https://doi.org/10.1101/2022.01.20.22269543; this version posted January 21, 2022. The copyright holder for this preprint (which was not certified by peer review) is the author/funder, who has granted medRxiv a license to display the preprint in perpetuity.

It is made available under a CC-BY-NC-ND 4.0 International license .

533 Table 1 - Population Demographics by Anti-S IgG quant

\begin{tabular}{|c|c|c|c|c|c|}
\hline \multicolumn{6}{|c|}{ Anti-S IgG Status } \\
\hline Variable & $\begin{array}{c}\text { Total } \\
\text { n (column \%) }\end{array}$ & $\begin{array}{l}\text { Positive } \\
\text { n (row \%) }\end{array}$ & $\begin{array}{l}\text { Negative } \\
\text { n (row \%) }\end{array}$ & $\begin{array}{l}\text { p-value } \\
\text { (All Data) }\end{array}$ & $\begin{array}{l}\text { RR (95\% Cl) } \\
\text { (All Data) }\end{array}$ \\
\hline Total & $1743(100.00)$ & $126(7.23)$ & $1617(92.77)$ & & \\
\hline Sex & & & & 0.31 & \\
\hline Female & $1306(74.93)$ & $102(7.81)$ & $1204(92.19)$ & & Referent \\
\hline Male & $431(24.73)$ & $24(5.57)$ & $407(94.43)$ & & $0.71(0.46,1.10)$ \\
\hline Nonbinary/3rd Gender & $3(0.17)$ & $0(0.00)$ & $3(100.00)$ & & $0.00(\mathrm{~N} / \mathrm{A})^{* *}$ \\
\hline Average Age (years) (SD) & $41.16(12.39)$ & $41.00(12.21)$ & $41.17(12.41)$ & 0.53 & \\
\hline BMI & & & & $\mathrm{p}<0.001^{*}$ & \\
\hline Underweight $\left(<18.5 \mathrm{~kg} / \mathrm{m}^{2}\right)$ & $34(1.95)$ & $0(0.00)$ & $34(100.00)$ & & $0.00(\mathrm{~N} / \mathrm{A})^{* *}$ \\
\hline Normal $\left(18.5-24.9 \mathrm{~kg} / \mathrm{m}^{2}\right)$ & $844(48.42)$ & $53(6.28)$ & $791(93.72)$ & & Referent \\
\hline Overweight $\left(25.0-29.9 \mathrm{~kg} / \mathrm{m}^{2}\right)$ & $528(30.29)$ & $29(5.49)$ & $499(94.51)$ & & $0.87(0.56,1.36)$ \\
\hline Obese $\left(>29.9 \mathrm{~kg} / \mathrm{m}^{2}\right)$ & $335(19.22)$ & $43(12.84)$ & $292(87.16)$ & & $2.04(1.40,2.99)$ \\
\hline Hispanic/LatinX & & & & 0.10 & \\
\hline Yes & $143(8.20)$ & $15(10.49)$ & $128(89.51)$ & & Referent \\
\hline No & $1594(91.45)$ & $109(6.84)$ & $1485(93.16)$ & & $0.65(0.39,1.09)$ \\
\hline Race & & & & 0.52 & \\
\hline White & $1299(74.53)$ & $87(6.70)$ & $1212(93.30)$ & & Referent \\
\hline Asian & $160(9.18)$ & $10(6.25)$ & $150(93.75)$ & & $0.93(0.50,1.76)$ \\
\hline Black & $141(8.09)$ & $13(9.22)$ & $128(90.78)$ & & $1.38(0.79,2.40)$ \\
\hline $\begin{array}{r}\text { Native American / } \\
\text { Pacific Islander }\end{array}$ & $7(0.40)$ & $0(0.00)$ & $7(100.00)$ & & $0.00(\mathrm{~N} / \mathrm{A})^{* *}$ \\
\hline Other & $123(7.06)$ & $12(9.76)$ & $111(90.24)$ & & $1.46(0.82,2.59)$ \\
\hline Smoking & & & & 0.77 & \\
\hline No & $1671(95.87)$ & $122(7.30)$ & 1549 (92.70) & & Referent \\
\hline Yes & $46(2.64)$ & $4(8.70)$ & $42(91.30)$ & & $1.19(0.46,3.09)$ \\
\hline
\end{tabular}

* Statistically significant when p-value $<0.05$

${ }^{* *} \mathrm{~N} / \mathrm{A}$ : unable to divide by 0

Column percentages may not always add up to $100 \%$ due to missing data of $<5.0 \%$ 
medRxiv preprint doi: https://doi.org/10.1101/2022.01.20.22269543; this version posted January 21, 2022. The copyright holder for this preprint (which was not certified by peer review) is the author/funder, who has granted medRxiv a license to display the preprint in perpetuity.

It is made available under a CC-BY-NC-ND 4.0 International license .

552 Figure 2 - Anti-S IgG by demographics - a). Age b). Gender c). Race

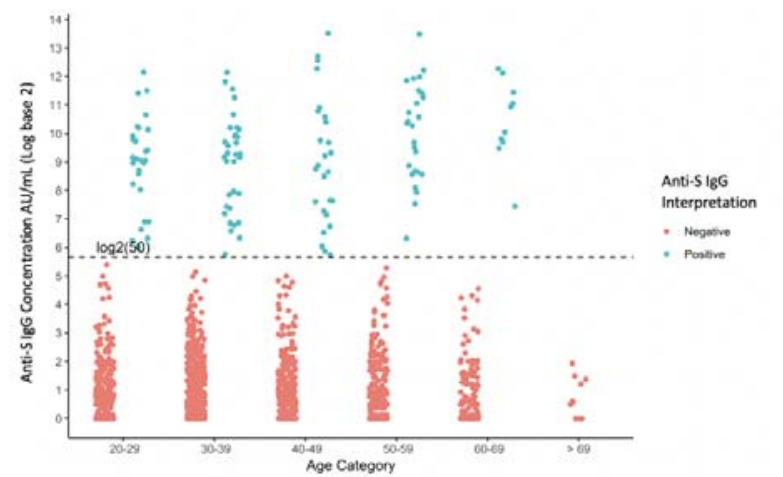

Fisher's Exact Test $P$ value: 0.53

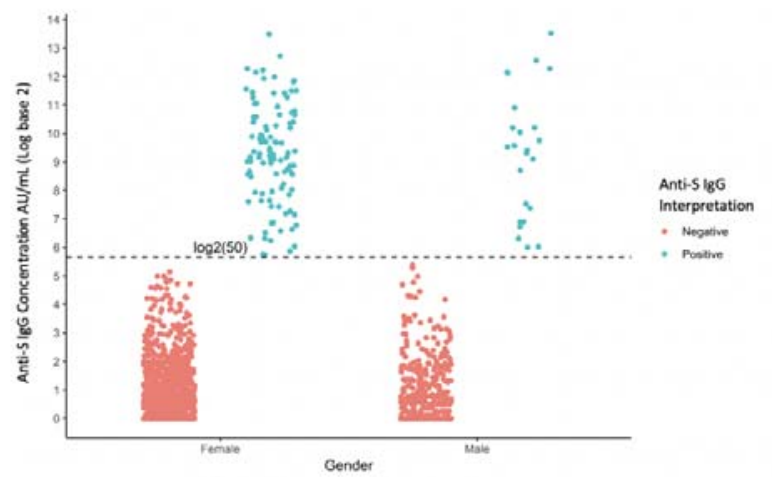

Fisher's Exact Test $P$ value: 0.12

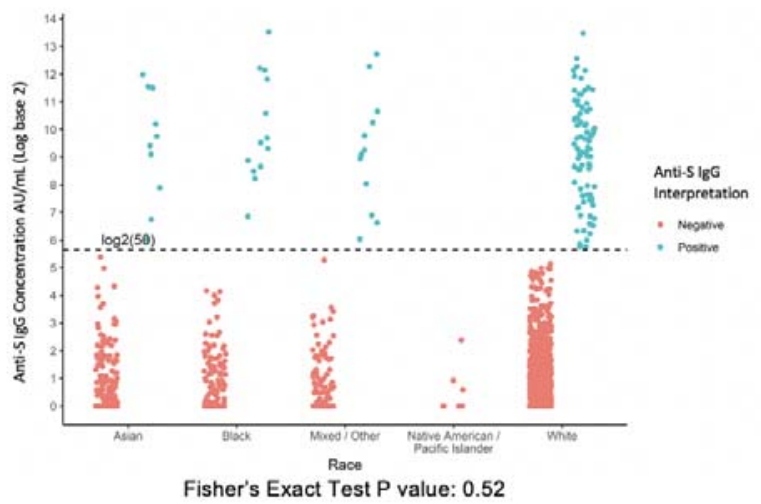

553

554

555

556

557

558

559

560

561

562

563

564

565

566

567

568

Table 2 - Anti-S IgG vs. SARS-CoV-2 RT-PCR

\begin{tabular}{|c|c|c|c|c|c|}
\hline \multicolumn{2}{|c|}{} & \multicolumn{4}{|c|}{ SARS-CoV-2 RT-PCR } \\
\cline { 2 - 6 } & & Positive & Negative & IND* & $\begin{array}{c}\text { Not } \\
\text { Tested }\end{array}$ \\
\hline \multirow{2}{*}{ Anti-S IgG } & + & 75 & 9 & 2 & 40 \\
\cline { 2 - 6 } & - & 10 & 341 & 4 & 1262 \\
\hline
\end{tabular}

*Indeterminate 
medRxiv preprint doi: https://doi.org/10.1101/2022.01.20.22269543; this version posted January 21, 2022. The copyright holder for this preprint (which was not certified by peer review) is the author/funder, who has granted medRxiv a license to display the preprint in perpetuity.

It is made available under a CC-BY-NC-ND 4.0 International license .

569 Figure 3 - Anti-S IgG distribution by SARS-CoV-2 RT-PCR status

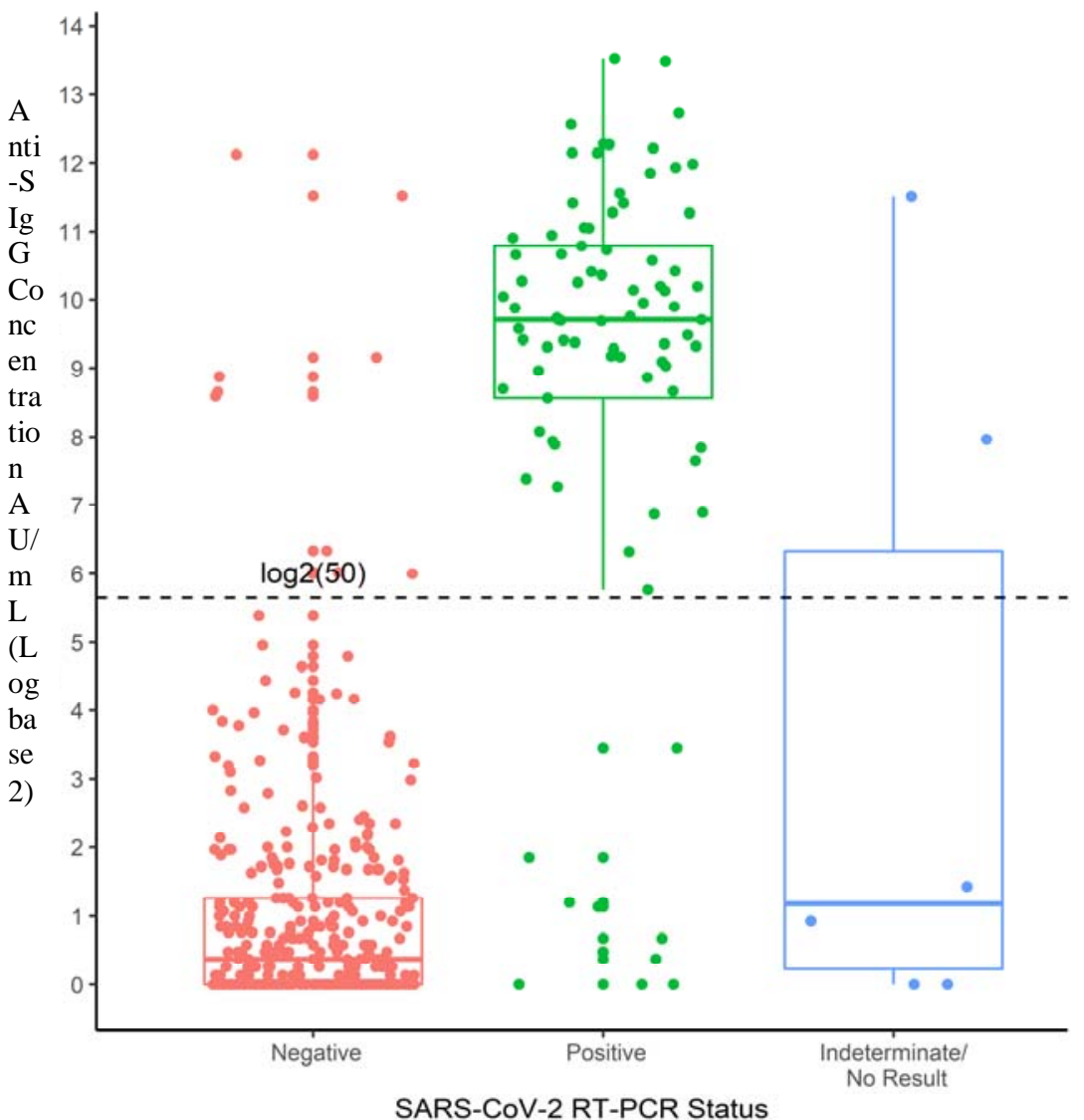

SARS-CoV-2 RT-PCR Status

(

571

Fisher's Exact Test $P$ value: $<0.0001$

572

573

574

575

576

577

578

579

580

581

582

583

584

585

586

587

588

589

590

591

592

593 
595 Figure 4 - Anti-S IgG distribution days post SARS-CoV-2 RT-PCR result

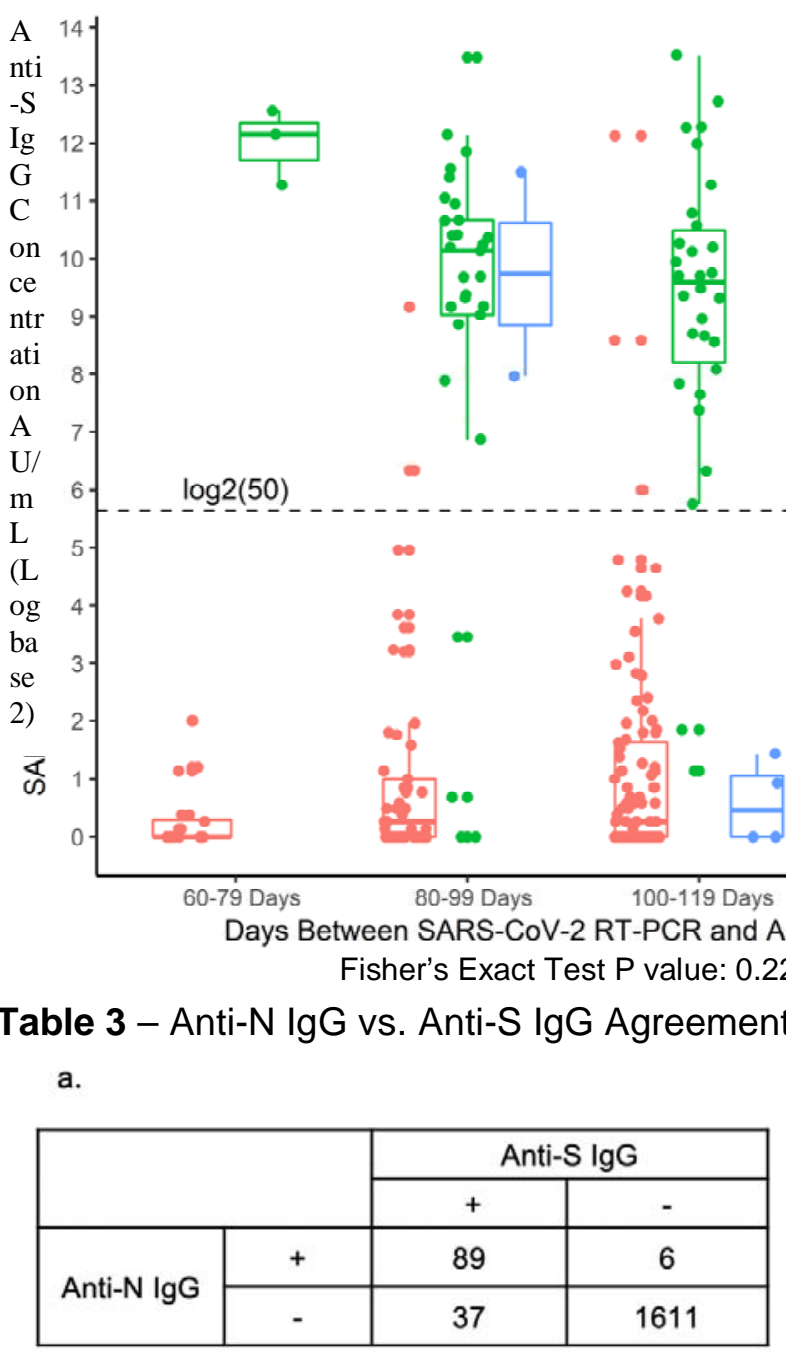

McNemar's Test Statistic with Yates' Continuity Correction: 20.93 P value: $<0.0001$ b.

\begin{tabular}{|c|c|c|c|}
\hline \multicolumn{2}{|c|}{} & \multicolumn{2}{c|}{ Anti-S IgG } \\
\cline { 3 - 4 } \multicolumn{2}{|c|}{} & + & - \\
\hline \multirow{3}{*}{ Anti-N IgG } & + & 109 & 21 \\
\cline { 2 - 4 } & - & 17 & 1596 \\
\hline
\end{tabular}

McNemar's Test Statistic with Yates' Continuity Correction: $0.24 \mathrm{P}$ value: $<0.0001$ 
medRxiv preprint doi: https://doi.org/10.1101/2022.01.20.22269543; this version posted January 21, 2022. The copyright holder for this preprint (which was not certified by peer review) is the author/funder, who has granted medRxiv a license to display the preprint in perpetuity.

614 